\title{
T. Квасникова
}

\section{ЖАНРОВЫЕ ИННОВАЦИИ КАМЕРНО-ВОКАЛЬНОГО ЦИКЛА В ТВОРЧЕСТВЕ ЛЮДМИЛЫ САМОДАЕВОЙ (НА ПРИМЕРЕ «ПЯТИ ИСТОРИЙ ПРО ХНЮ»)}

В данной статье проводится анализ иикла Л. Самодаевой «Пять историй про Хню», благодаря которому данное произведение можно отнести к авторской жанровой номинации мини-моноопера. Данная жанровая форма объединила в себе черты вокального цикла и камерной оперы, что соответствует тенденции жанровой интерференции, которая активно используется современными композиторами.

Ключевые слова: мини-моноопера, камерный вокальный жсанр, интерференция.

Жанровые черты цикла Людмилы Самолаевой «Пять стихотворений про Хню» обобщены в определении, которое становится авторской жанровой номинацией - мини-моноопера. Данная новаторская, но уже достаточно активно используемая современными композиторами жанровая форма соединяет черты вокального цикла и камерной оперы, усиливая их близость друг к другу, то есть является переходной. Интерес к ней, на наш взгляд, объясняется стремлением композитора расширить и усложнить ту эстетическую идею, которая является общим основанием цикла.

Именно в начале XXI века обнаруживается устойчивая тенденция скрещивать камерно-вокальный цикл с оперой, а оперу наделять той психологической глубиной и лирической интимностью, которая свойственна камерно-вокальной музыке, в том числе камерному вокальному исполнительству. В русле данной тенденции вырастают такие новые поджанры, как камерная опера, моноопера, дуоопера, некоторые другие [3].

В последнее десятилетие моноопера существенно расширяет жанровый спектр выразительных средств, создающих музыкальную характеристику персонажа в рамках монологического высказывания, подготавливая, таким образом, рождение новых художественных форм. Ее ответвлением, связанным, во-первых, с заметным сокращением масштабов композиционного целого, во-вторых, с детализированным преподнесением словесного содержания и его необычным характером становятся такие разновидности, как «мини-моноопера» и «микро-моноопера» [2]. 
Отличие между данными двумя ответвлениями монооперы еще весьма условны. Тем не менее можно уже говорить о том, что для «мини-монооперы» показательной является особенная близость к камерному вокальному циклу и усиление выразительно-смысловой роли музыкального начала. «Микро-моноопера» позиционирует себя, скорее, как театральный жанр, для которого важнее всего речевая экспрессия, следовательно, речитативные свойства вокального голоса. Обе данные разновидности развиваются в творчестве современных одесских композиторов - Кармеллы Цепколенко, Юлии Гомельской, Людмилы Самодаевой [2]. Поэтому главной задачей данной статьи является аналитическое определение жанрово-композиционных принципов мини-монооперы Л. Самодаевой «Пять историй про Хню».

Камерный вокальный жанр для Людмилы Самодаевой является основным, наиболее близким способом мироощущения и самооценки. В основу ее произведений легли тексты, написанные современными поэтами, благодаря которым возникли вокальные циклы на стихотворении Ивана Драча, Беллы Ахмадулиной, Юнны Мориц, Арсения Тарковского. А среди принадлежащих ей камерных опер в последние годы заставила о себе говорить опера «Двойной Леон» по одноименному роману Юрка Издрыка, который покорил композитора своим языком, интонацией, ритмом и композицией.

Стихотворения Хармса привлекли Л. Самодаеву своей парадоксальностью - граничащей с абсурдом словесной игрой, за которой проглядывают сложные и весьма серьезные социальные и психологические проблемы. Словесные парадоксы и игра смыслов побудили композитора к созданию мини-монооперы «Пять историй про Хню» для сопрано и виолончели на слова Д. Хармса.

Мини-моноопера «Пять историй про Хню» на стихи Даниила Храмса была написана композитором в декабре 2010 года. Премьера состоялась на семнадцатом фестивале «Два дня и две ночи новой музыки» в исполнении дуэта из Швейцарии Франциски Вельт (сопрано) и Морица Мюлленбаха (виолончель) - замечательных исполнителей, которые неоднократно представляют произведения одесских композиторов.

Хню - это имя лесной девы. По рассказам, в комнате Хармса одно время висела картина художника Петра Соколова «Лесная девушка», которая, видимо, и дала толчок к созданию этого образа и написании поэмы «Хню» [5]. 
Композитор отбирает из стихотворения части, связанные именно с образами девушки и природы, сохраняя при этом последовательность изложения текста. Ниже приводим таблицу, в которой представлены: в левой колонке - оригинал текста Д. Хармса (курсивом отображен текст который не вошел в мини-монооперу), в правой избранный текст Л. Самодаевой, пронумерованный в соответствии с номерами произведения.

\section{Оригинал текста стихотворения} «Хню» Д. Хармса

Хню из леса шла пешком. Ногами месила болота и глины. Хню питалась корешком рога ворона малины. Или Хню рвала побеги Веселого хмеля, туземца рощ. Боги ехали в телеге. Ясно чувствовалась мощь богов, наполненных соком лиан и столетних нев.

И мысль в черепе высоком лежала, вся окаменев.

Зубами щелкая во мху, грудь выпятив на стяги, варили странники уху, летали голые летяги, подвешиваясь иными моментами на сучках вниз головой.

Они мгновенно отдыхали, то поднимая страшный вой, в котел со щами устремляясь, хватая мясо в красную пасть.

То снегири летели в кучу печиков, то медведь, сидя на дереве и запустив когти в кору, чтобы не упасть, рассуждал о правосудии кузнечиков. То Бог в кустах нянчил бабочкину куколку, два волка играли в стуколку таков был вид ночного свидригала, где Хню поспешно пробегала и думала, считая пни сердечного биения.

\section{Избранный текст стихотворения композитора}

\section{1}

Хню из леса шла пешком.

Ногами месила болота и глины.

Хню питалась корешком рога ворона малины. Или Хню рвала побеги Веселого хмеля, туземца рощ. В поле ехали в телеге. Ясно чувствовалась мощь воздушного неба и ветра злой гнев.

И люди выкупавшись в речке лежали, все окаменев. Зубами щелкая во мху, грудь выпятив на стяги, варили странники уху, летали голые летяги, подвешиваясь иными моментами на сучках вниз головой.

Они мгновенно отдыхали, то поднимая страшный вой, в котел со щами устремляясь, хватая мясо в красную пасть. То снегири летели в кучу печиков, то медведь, сидя на дереве и запустив когти в кору, чтобы не упасть, рассуждал о правосудии кузнечиков. То Бог в кустах нянчил бабочкину куколку, два волка играли в стуколку таков был вид ночного свидригала, где Хню поспешно пробегала и думала, считая пни сердечного биения. 
Аскет в пустыне - властелин, бомба в воздухе - владычица, оба вместе - лучшее доказательство человеческого гения.

Пусть комета в землю тычется, угрожая нарушить бег нашей материи.

И, если пена - подружка огня на черном кратере

выпустит мух с небесными каракульками на лапках, мы гордо глядим на вулкан

u, в папках

земных дел

отмечаяя рукой астронома событие, способное закидать дредноут лепестками вишни, мы превратили мир в народное увеселение

и всюду увеличили плотность населения.

Еще недавно кверху носом летал Юnuтер, в 422 года раз празднуя свои именины, пока шутливая комета не проскочила в виде миски

в хрустальном животе Глафиры.

Пропали быстро звездные диски, Исчезли тонкие эфиры, даже в пустынях арифметики не стало сил аскету пребывать в одиночестве.

Хню шла вперед и только отчасти скользила кверху гибким станом. Сел свет, рек звон, лесов шуршание ежеминутно удалялись.

Хню пела. Чистые озера, кой-где поблескивая, валялись.

То с шумом пролетал опасный овод, то взвизгивал меж двух столбов гремучий провод,

сидя на белых изоляторах. То лампы освещали каменные кочки ногам приятные опоры в пути воздушного болота, то выли дерзкие моторы в большие вечные ворота.
2

Хню шла вперед и только отчасти скользила кверху гибким станом. Сел свет, рек звон, лесов шуршание ежеминутно удалялись. Хню пела. Чистые озера, кой-где поблескивая, валялись. То с шумом пролетал опасный овод, то взвизгивал меж двух столбов гремучий провод, сидя на белых изоляторах. То лампы освещали каменные кочки ногам приятные опоры в пути воздушного болота, то выли дерзкие моторы в большие вечные ворота. Иной раз беленький платочек садился на верхушку осины. 3

Хню хлопала в ладоши.

Яркие холмы бросали тонкие стрелы теней.

Хню прыгала через овраги, и тени холмов превращали Хню в тигрицу.

Хню, рукавом смахнув слезинку. бросала бабочек в плетеную корзинку.

Лежите, бабочки, и вы, пеструшки, крестьянки воздуха над полевыми клумбами.

И вы, махатки и свистельки, и вы, колдунки с бурыми бочками и вы, лигреи, пружинками хоботков сосите, милые, цветочные кашки. И вы, подосиновые грибы станьте красными ключами. Я запру вами корзинку, чтобы не потерять мое детство.

4

Хню к телеграфному столбу

Для отдыха прислонилась.

Потухли щеки Хню. Во лбу окно стыдливое растворилось. В траве бежала змейка, высунув гибкое жало, в ее глазах блестела чудная копейка. 
Иной раз беленький платочек садился на верхушку осины.

Хню хлопала в ладоши.

Яркие холмы бросали тонкие стрелы теней.

Хню прыгала через овраги, и тени холмов превращали Хню в тигрицу.

Хню, рукавом смахнув слезинку. бросала бабочек в плетеную корзинку.

Лежите, бабочки, и вы, пеструшки, крестьянки воздуха над полевыми клумбами.

И вы, махатки и свистельки, и вы, колдунки с бурыми бочками и вы, лигреи, пружинками хоботков сосите, милые, цветочные кашки. вы меченосиы военными лапами бейте славянок вы избачи с медалями ваших сражений на плоскости крыльев гряньте куркуру вы портные с выкройками из газет вспомните профессора Чебышева И вы, подосиновые грибы станьте красными ключами. Я запру вами корзинку, чтобы не потерять мое детство. Хню к телеграфному столбу Для отдыха прислонилась. Потухли щеки Хню. Во лбу окно стыдливое растворилось. В траве бежала змейка, высунув гибкое жало, в ее глазах блестела чудная копейка. Хню медленно дышала, накопляя растраченные силы и распуская мускулов тугие баночки. Она под кофточкой ошупывала груди.

Она вообще была прелестной паночкой.

Ах, если б знали это люди! Нам так приятно знать прошедшее. Приятно верить в утвержденное.
Хню медленно дышала, накопляя растраченные силы и распуская мускулов тугие баночки. Она под кофточкой ощупывала груди.

Она вообще была прелестной паночкой.

Ах, если б знали это люди!

$$
5
$$

Хню, отдохнув, взмахнула сильными костями

и двинулась вперед.

Вода послушно расступилась.

Мелькали рыбы. Холодело.

Хню, глядя в дырочку, молилась, достигнув логики предела.

«Меня уж больше не тревожит земля, ведушая беседу о прекращении тепла, шептала Хню своему соседу. Меня уж больше не атакуют пути жука-точильщика, и гвозди больше не кукуют в больных руках могильщика. И если бы все пчелы, вылетев из чемодана, в меня направили б свои тупые жала, то и тогда, поверьте слову, от страха вовсе б не дрожала». - «Ты права, моя голубка, отвечает путник ей, но земель глухая трубка полна звуков, ей-же-ей.» Хню ответила: «Я дурой рождена сидеть в стогу, полных дней клавиатуры звуков слышать не могу. И если бабочки способны слышать потрескивание искр в кореньях репейника, и если жуки несут в своих котомках ноты расточительных голосов, и если водяные паучки знают имяотчество оброненного охотником пистолета, то надо сознаться, что я просто глупая девочка». 
Тысячи раз перечитывать книги, доступные логическим правилам. Охаживать приятно темные угль наук.

Делать веселые наблюдения.

И на вопрос: есть ли Бог? - поднимаются тысячи рук,

склонные полагать, что Бог - это

выдумка.

Мы рады, рады уничтожить

наук свободное полотно.

Мы считали врагом Галилея, давшего новые ключи.

А ныне пять обэриутов, еще раз повернувшие ключи в арифметиках веры, должны скитаться меж домами за нарушение обычных правил рассуждения о смыслах.

Смотри, чтоб уцелела шапка, чтоб изо лба не выросло бы дерево, тут мертвый лев сильней живой собаки, u, право, должен я сказать, моя изба не посещается гостями.

Хню, отдохнув, взмахнула сильными костями

и двинулась вперед.

Вода послушно расступилась.

Мелькали рыбы. Холодело.

Хню, глядя в дырочку, молилась, достигнув логики предела.

«Меня уж больше не тревожит земля, ведущая беседу

о прекращении тепла, шептала Хню своему соседу. Меня уж больше не атакуют пути жука-точильщика, и гвозди больше не кукуют в больных руках могильщика. И если бы все пчелы, вылетев из чемодана,

в меня направили б свои тупые

жала, то и тогда, поверьте слову, от страха вовсе б не дрожала». - «Ты права, моя голубка, -
- «Вот это так,- сказал ей спутник, - всегда наивысшая чистота категорий пребывает в полном неведении окружающего.

И это, признаться, мне страшно нравится».

Bce! 
отвечает путник ей, но земель глухая трубка полна звуков, ей-же-ей». Хню ответила: «Я дурой рождена сидеть в стогу, полных дней клавиатуры звуков слышать не могу. И если бабочки способны слышать потрескивание искр в кореньях репейника, и если жуки несут в своих котомках ноты расточительных голосов, и если водяные паучки знают имяотчество оброненного охотником пистолета, то надо сознаться, что я просто глупая девчонка».

- «Вот это так, - сказал ей спутник, - всегда наивысшая чистота категорий пребывает в полном неведении окружающего.

И это, признаться, мне страшно нравится».

Bce!

Основной текст стихотворения практически не изменяется. Лишь в первом номере композитор заменяет строки: «Боги ехали в телеге. Ясно чувствовалась мощь богов, наполненных соком лиан и столетних нев. Имысль в черепе высоком лежала, вся окаменев», на текст «В поле ехали в телеги. Ясно чувствовалась мощь воздушного неба и ветра злой гнев. И люди, выкупавшись в речке, лежали все окаменев». Таким образом, в отличие от Даниила Хармса, Самодаева отказывается от слова «боги», сохраняя противопоставление образов Хню, природы и людей.

В музыкальном отношении мини-монооперу можно разделить на три образные сферы. Первая, в которой превалируют глиссандирующие мелодические линии, связана с образом Хню. Контрастом для скользящих интонаций Хню выступает брутальная, четко фиксированная речевая интонация. Часто она сопровождается аккордовыми комплексами токкатного плана. Эта агрессивная манера изложения текста содержит характеристику приземленных мирских существ людей. По мысли Д. Хармса, все человеческое смертно, и лишь душа 
является бессмертной категорией, обладающей «наивысшей чистотой категорий». Посредником между грубым миром людей и эфемерной чистотой души является третий образ - образ природы. Природа в данном стихотворении выступает у автора как позитивное начало, источник жизни. У Хармса Хню, которая тесно связана с природой, это не просто лесное существо в образе девушки, но - человеческая душа в поиске пристанища. Рисуемый поэтом мистический лес тернистый путь, по которому блуждает эта душа, пребывающая в «полном неведении окружающего».

Музыкальный язык цикла Л. Самодаевой и графически тонок, и семантически сложен; чтобы облегчить задачу воспроизведения-интерпретации словесного материала, композитор дробит цикл на словесно- и музыкально-смысловые цифры. Всего таких цифр 43, разделенных по 5 основным номерам. Между номерами-сценами есть паузы, позволяющие исполнителям сменить сценическую площадку.

$\boldsymbol{B}$ первом номере (andante) 1-2 цифры в словесном изложении представляют экспозицию образа Хню. 2-8 цифры уделены месту обитания Хню - лесу и его окрестностям, 9-я - возвращает образ лесной девы. Такая же 3-частность соблюдается в музыкальном изложении, в котором экспозиционный и заключительный разделы интонационно переплетаются друг с другом, а их объединяющим звеном становится интервал ум. 8 с последующим разрешением (фа\#-фа в pe, сменяющийся ре b).

Bmopoŭ номер (andantino con moto), в котором ведущей оказывается вокальная партия, разделяется на три различные части. Вокальной партии поручается игриво-непосредственное начало номера. В нисходящем движении проходит фраза, изломанная форшлагами, и она же закрывает экспозиционный раздел. Таким образом, начальный материал четко отграничен. Как эхо, за вступлением партии у вокалиста звучит голос виолончели, переходящий в глиссандирующий аккомпанемент в 10-й цифре. В вокальной партии в это время звучит основная тема второго номера, заключающий в себе вопросительную интонацию. С 12-й цифры начинается новый материал, активнее становятся обе партии. 13-я - знакомая ломаная мелодия, но на этот раз она звучит в восходящем движении. С этой же цифры начинается последняя часть номера, интонационно переплетающаяся с основным материалом первой части номера.

Tретий номер (gaio) начинается в более подвижном темпе. Скерцозно-танцевальный характер его звучанию придают хлопки во 
вступительной части. Здесь Хню - игривое дитя природы. Мелодия вокальной партии звучит отрывисто и легко, а номер построен на контрастных сопоставлениях. На смену легкости и игривости приходят распевные лирические интонации. Заканчивается номер одновременным растворяющимся глиссандо у обоих исполнителей, сопрано и виолончелиста, интонационно близким материалу второго раздела.

Четвертый номер (slowly, rubato molto) выписан в партитуре уже для трех участников. Появляется партия для голоса, которую исполняет (поет) виолончелист. В современной музыке подобное явление - функциональное расщепление партии исполнителя встречается довольно часто. Данный номер является наиболее напряженным и драматичным. Он начинается с вопросительной интонации основной темы второго номера, но на этот раз она проходит в партии виолончели. В вокальной партии используются специфические приемы звукоизвлечения, например, имитирование рикошета струнных.

Hомер nяmb (con moto) является для композитора кульминационным и самым масштабным. Вокалист в данном номере излагает поэтический материал от имени 3 персонажей - Хню, ее спутника и рассказчика, - каждому из которых присуща своя музыкальная характеристика. Музыка рассказчика спокойна, распевна; он повествует о судьбе Хню. Ее речь представлена отрывистой, легкой, акцентированной мелодией. Партии спутника-соседа присуща нарочитая трехдольность, а его интонационный строй близок романсовому типу изложения, здесь явно выступающему пародией.

В целом, цикл Людмилы Самодаевой предстает ярким случаем жанровой интерференции, возникающей на основе художественного диалога поэта и композитора. Интерференция - как наложение, совмещение различных форм и способов экспликации художественного замысла - является важнейшей предпосылкой реализации программных установок камерно-вокального произведения в их широком значении. Она получает наиболее «чистое» и полное выражение именно в искусстве, которое объективирует, опредмечивая и означая, психологические процессы, происходящие в сознании субъекта творчества.

Внимание к явлению интерференции предполагает изучение способов взаимодействия со словом, принятых в камерно-вокальном творчестве, в их зависимости от устойчивых жанровых тенден- 
ций данного творчества и в их программной действенности для этих форм [4].

Таким образом можно прийти к выводу, что в цикле Людмилы Самодаевой особенно рельефно предстает тот аспект игры-театрализации камерного вокального произведения, который обусловлен синтезом композиторского и поэтического замыслов, связан с моделированием в музыке не столько содержания отдельного стихотворения, сколько его ведущей творческой идеи: парадоксальной свободы в восприятии и оценке реалий окружающего мира. Таким образом воссоздается и образ Поэта как обретенной в диалоге, близкой по духовным стремлениям, личности.

\section{СПИСОК ЛИТЕРАТУРЫ}

1. Александров А. Чудодей: Личность и творчество Даниила Хармса / А. Александров // Хармс Д. Полет в небеса. - Л. : Советский писатель, 1988. - C. 7-48; 505-555.

2. Розенберг Р. Специфические черты и жанровые инновации в современном оперном творчестве одесских композиторов / Р. Розенберг // Музичне мистецтво і культура. Науковий вісник Одеської державної консерваторії ім. А. В. Нежданової ; [гол. ред. О. В. Сокол]. - Одеса : Друкарський дім, 2011. - Вип. 14. - С. 129-136.

3. Розенберг Р. Русская опера малой формы конца XIX начала XX века : дис. ... канд. искусствоведения / Р. Розенберг. - Л., 1967. - 249 с.

4. Ручьевская Е. О соответствии слова и мелодии в русской камерно-вокальной музыке начала XX века / Е. Ручьевская // Русская музыка на рубеже XX века : статьи, сообщения, публикации / [общ. ред. М. К. Михайлова, Е. М. Образцова]. - М. - Л., 1966. - С. 65-112.

5. Хармс Д. Полное собрание сочинений : в 4 т. / Д. Хармс ; [сост., подгот. текста и прим. В. Н. Сажина]. - СПб. : Академический проект, 1997-1999. Tт. $1-3$.

Квасникова Т. «Жанрові інновації камерно-вокального циклу у творчості Людмили Самодаєвої (на прикладі циклу «П'ять історій про Хню»). У даній статті проводиться аналіз циклу Л. Самодаєвої «П'ять історій про Хню», завдяки якому даний твір можна віднести до авторської жанрової номінації міні-моноопера. Дана жанрова форма об'єднала в собі риси вокального циклу та камерної опери, що відповідає тенденції жанрової інтерференції, яка активно використовується сучасними композиторами.

Ключові слова: міні-моноопера, камерний вокальний жанр, інтерференція. 
Kvasnikova T. «Genre innovations of a chamber and vocal cycle in Lyudmila Samodayeva's creativity (on the example of the cycle «Five Stories about Hnyu»). In this article the analysis of a cycle «Five Stories about Hnya» of L. Samodayeva, thanks to which, this work can be referred to the author's genre nomination the mini-monoopera is carried out. This genres form united in itself lines of a vocal cycle and the chamber opera that corresponds to a tendency of a genre interference which is actively used by modern composers.

Keywords: mini-monoopera, chamber vocal genre, interference.

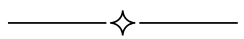

УДК 78.01

\section{Ю. Фурдуй \\ МУЗЫКАЛЬНЫЙ РИТМ КАК МУЗЫКОВЕДЧЕСКАЯ КАТЕГОРИЯ}

В статье понятие ритма рассматривается в двух его основных аспектах: широком и узком. Установлено, что «ритм» в качестве музыкальной категории может трактоваться как одна из категорий диалектического развития. Также наличие широкого и узкого определения ритма определяет его движение на всех уровнях музыкального целого: синтаксическом (музыкальный ритм в узком значении), композиционном и драматургическом (ритм в широком смысле слова) и жанрово-стилевом (ритм в самом широком понимании).

Ключевые слова: ритм, музыкальный ритм, драматургический ритм, композиционный ритм, смысловой ритм, жанрово-стилевой ритм.

Ритм - явление фундаментальное, как в природе, так и в искусстве. Он может проявлять себя в различных процессах и формах, в повторяемости и цикличности, в множественности и разнообразии. Постижение процессуальности существования музыкального жанра происходит через понимание пространства и времени. Данные категории неразделимы и оформляются в нашем сознании с помощью ритма, который, в свою очередь, обнаруживает структурно-организационные качества. Понятие о ритме используется широко во всех общегуманитарных, а также музыковедческих направлениях. Полисемия категории «ритм» и диссонанс в ее дефиниции потребовали детального разбора содержания понятийного аппарата теории ритма.

Ритм на протяжении длительного времени привлекает внимание не одного поколения исследователей. Философия, литературоведе- 